\title{
Integrating Technological Acceptance Model and End-User Computing Satisfaction to Explain the Intention to Continue Using Car Navigation Systems in UAE
}

\author{
Salem Alkutbi, Ibrahim Alrajawy, Ali Ameen, Ahmed Hamoud Al-Shibami, Amiya Bhaumik
}

\begin{abstract}
This research uses modelling of structural equations via PLS to assess the 167 suitable questionnaires so as to evaluate the recommended model that utilizes the technology acceptance model TAM and end-user computing satisfaction theories to identify factors that affect driver intention to continue using car navigation systems among UAE's drivers with private licenses. The research will describe relationships among accuracy, content, format, timeliness, ease of use, perceived usefulness, and intention to continue using car navigation systems. Our efforts have improved our understanding of the use of satellite navigation technology. Results suggested that all seven hypotheses are supported. The recommended model also clarified $20 \%$ of the variance in the intention to continue using car navigation systems.
\end{abstract}

Keywords : intention to continue using car navigation systems; TAM; EUCS; UAE.

\section{INTRODUCTION}

To o fulfil consumer demand for comfort, energy saving, small technology, and safety, the automotive industry amplified the amount of vehicles containing electronic products each year. A car owner who fixes a car navigation system (CNS) anticipates to make use of it to evade tough driving conditions, such as traffic jams, or to swiftly determine the best routes when driving in unfamiliar locations or when lost. The latest spread of in-car navigation systems (Satnav) is the result of the development of Global Navigation Satellite Systems (GNSS), the advances in hardware such as resolution, processing power, and screen size, in addition to the improvements in the gathering and visualization of geographic information such as navigable map databases and in-vehicle sensors. The outcome gadgets fulfil drivers' need to improve the comfort, safety and their travel efficiency.

\section{Revised Manuscript Received on September 25, 2019}

Salem Alkutbi, Faculty of Business and Accountancy, Lincoln University College, Selangor, Malaysia

Ibrahim Alrajawy, Faculty of Business and Accountancy, Lincoln University College, Selangor, Malaysia

Ali Ameen, Faculty of Business and Accountancy, Lincoln University College, Selangor, Malaysia

Ahmed Hamoud Al-Shibami, Faculty of Business and Accountancy, Lincoln University College, Selangor, Malaysia

Amiya Bhaumik, Faculty of Hospitality and Tourism, Lincoln University College (LUC), Selangor, Malaysia
The United Arab Emirates (UAE) is a rapidly developing high-income country and the number of motor vehicles has increased rapidly. It is clear that the UAE is trying to become a leading technology centre based on the innovation strategy of the 4th Industrial Revolution [1]. As per the police database, there is a growth in the road accident and injuries along with the increase in the construction of many high-speed modern motorways. The main problem behind this increase is the lack of proper safety measures for both adults and children. UAE nationals are more under death risks while driving a car. Factors like age, sex, and nationality, vehicle factors, locations of incidents along with the road user types are termed as the variables of interest in such incidents. In most contemporary organizations, adopting technology is not only uses ICT to fill up some forms and records but rather it is also a tool that performs the process of identification, accumulation, analysis, measurement, preparation, interpretation and communication of the information used by management to plan [2-3] It is used in evaluating and controlling within an organization and to assure appropriate use and accountability for their resources [2,3,5]. Various global indicators will help in understanding the position of UAE according to a set of measures that are recognized internationally.

This study aims at examing the effect of car navigation system characteristics based on the end-user computing satisfaction EUCS on the driver's intention to continue using car navigation systems among drivers with private licenses in the United Arab Emirates.

\section{Literature REVIEW}

\section{A. Ease-of-Use (EOU) and Perceived Usefulness (PU)}

Technology Acceptance Model (TAM) is broadly utilized to understand technology adoption and usage. Among its positive features is robustness [6] and this has been the reason for its vast reputation in the information system field and among IT practitioners. There are two fundamental elements of TAM (ease of use and perceived usefulness) which influence user intention to adopt technology [7]. Ease of use is defined as the extent to which an individual considers that using a specific system would effortless, while

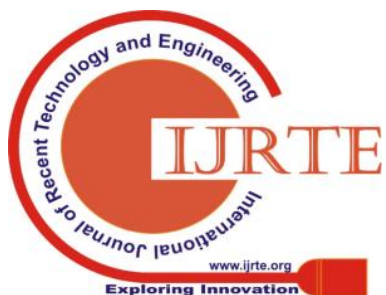


perceived usefulness is defined as the extent to which an individual considers using a particular system would improve his performance [7]. These two main important variables of TAM are empirically established to be substantial as determinants of user intention to adopt diverse technological applications and cultural contexts [8, 9] (. Consequently, the following hypotheses are proposed:

H1: Ease-of-use has a postive effect on perceived usefulness.

H6: Ease-of-use has a postive effect on intention to continue using car navigation systems.

H7: Perceived usefulness has a postive effect on intention to continue using car navigation systems.

\section{B. End-User Computing Satisfaction (EUCS)}

A technology or information system that fulfils the needs of a user strengthens satisfaction with the system which can be a subjective indicator of system success. User satisfaction and usage are the two frequently used measures for technology application success. Previous studies have reported that user satisfaction is significantly associated to the benefit of technology application giving strong empirical support to the common assumption of user satisfaction being the most suitable indicator of technology success. Further he claims that end-user computing satisfaction model (EUCS) is a good determinant of a technology's benefit or impact. EUCS is an instrument that consists of 12-item questionnaire about user satisfaction with a technology application or information system. It comprises of five constructs: format, accuracy, timeliness, content, and ease of use (. The EUCS model was selected for this study due to two reasons. First, because the aim of our study is to investigate user satisfaction with car navigation system, the EUCS model appears to be the most appropriate in this context. Second, the EUCS model has been validated and verified by many studies. In certain models satisfaction is used only as a factor of a larger model to predict the usefulness of certain technology, but in the EUCS model satisfaction is the sole dependent variable. Consequently, the following hypothesis is proposed:

$\mathrm{H} 2$ : Accuracy has a postive effect on perceived usefulness. H3: Content has a postive effect on perceived usefulness.

H4: Format has a postive effect on perceived usefulness.

H5: Timeliness has a postive effect on perceived usefulness.

\section{Intention to Continue Using Car Navigation Systems (INT)}

Intention refers to the intentional and purposeful aim to take on a certain novel undertaking, consequently is connected to the concept of using, whereby the intentions directly influence the rate of usage. Hence, usage or actual adoption is intimately dependent on intention. Noticeably, users' intentions are also dependent on their understanding of the system or technological application, potential benefits, and perceived risk. For the purpose of this research, intention to continue using the technology specifically targets the innovation of car navigations systems. Intention to accept and use different applications of technology has been studied through years and in different contexts. The intention to adopt is affected by a variety of factors that are related to customer behavior. Through the systematic literature review, many scholars have studied the intention as the dependent variable of their studies [10-12].

\section{RESEARCH METHOD}

\section{A. Overview of the Proposed Conceptual Framework}

The correlations between the parameters conjectured in the conceptual model have been obtained from the Technology Acceptance model and end-user computing satisfaction model. Fig 1 displays the recommended model that includes perceived usefulness, ease of use, and intention to continue using car navigation systems. These correlations are adapted from [7]. Moreover, accuracy, content, format, and timeliness are adapted from. The given model evaluates the relationship among the aforementioned aspects for the UAE's drivers with private licenses. The proposed conceptual framework has seven hypotheses to be tested.

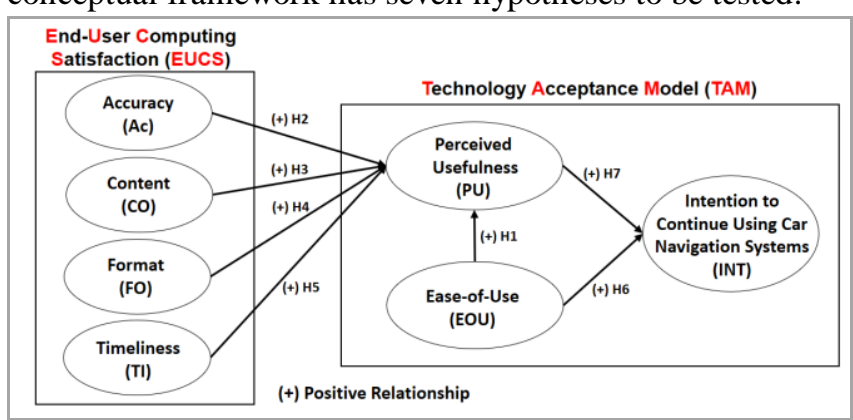

Fig. 1: The proposed conceptual framework

\section{B. Development of Instrument and Data collection}

The creation of a tool for this research involved a questionnaire of 17 questions, and on the basis of the literature on IS, the research employed a multi-item Likert scale. The parameters were evaluated using a Likert scale recommended in the earlier studies [13,14]. The information was gathered by delivering a self-managed questionnaire 'in-person' between March to May 2018 to UAE's drivers with private licenses. Nearly 220 questionnaires were distributed, out of which only 180 were returned. About 167 responses of the returned sets were filtered for the current study. However, based on the prior study limitations [15], the final sample size was insufficient to conduct the analysis.

\section{Data Analysis AND Results}

Partial Least Squares (PLS) and Structural Equation Modelling-Variance Based (SEM-VB) were employed to assess the research model by utilizing the software SmartPLS 3.0. A two-phase analytical technique consisting of (i) measurement model analysis (reliability and validity) and (ii) structural model analysis (examining the conceptualised relationships) was employed after performing the descriptive assessment. This two-phase analytical technique consisting of a structural and a measurement model assessment is better than a single phase assessment. While the model of 
measurement explains each parameter's measurement, the structural model describes the correlation between the parameters in this model.

\section{A. Descriptive analysis}

Table 1 discusses about the mean and SD values of each and every variable of the present study. The respondents were asked to share their opinion using the 5-pointer Likert's scale about the transformational leadership and human capital based. Accuracy score was found to be highest with mean value of 3.637 out of 5.0, with a standard deviation of 1.134 .

\section{B. Measurement Model Assessment}

Construct reliability as well as validity (comprising discriminant and convergent validity) were used to examine the measurement model. The particular alpha coefficients of Cronbach were tested to determine the reliability of every core parameter in the measurement model (construct reliability). The quantities of all the unique alpha coefficients of Cronbach in this research ranged from 0.863 to 0.946 , which went beyond the proposed value of 0.7 [16]. Moreover, for inspecting construct reliability, all the CR (composite reality) values ranged from 0.936 to 0.974 , which went beyond $0.7[17,18]$. Thus, as Table 1 shows, construct reliability has been fulfilled as Cronbach's CR and alpha were rather error-free for all the parameters.

Analysis of indicator reliability was conducted by utilising factor loadings. When the related indicators are very similar, this is reflected in the construct and signified by the construct's high loadings. As per the previous studies, the exceeding of values beyond 0.70 suggests substantial factor loadings. Table 1 displays that all articles in this research had factor loadings greater than the suggested value of 0.7 . AVE (average variance extracted) was employed in this study to analyse convergent validity, which represents the degree to which a measure is correlated positively with the same construct's other measures. All the AVE values ranged from 0.850 and 0.949 , which went beyond the proposed value of 0.50 . Thus, all constructs have complied with the convergent validity acceptably, as shown in Table 1

Table 1: Mean, standard deviation, loading, cronbach's Alpha, CR and AVE

\begin{tabular}{|c|c|c|c|c|c|c|c|}
\hline Constructs & Item & $\begin{array}{l}\text { Loadin } \\
\qquad \begin{array}{l}\mathrm{g} \\
(>0.5)\end{array}\end{array}$ & M & SD & $\begin{array}{c}\alpha \\
(> \\
0.7)\end{array}$ & $\begin{array}{c}\mathrm{CR} \\
(>0.7)\end{array}$ & $\begin{array}{c}\text { AVE } \\
(>0.5)\end{array}$ \\
\hline $\begin{array}{l}\text { Ease-of-Use } \\
\text { (EOU) }\end{array}$ & $\begin{array}{l}\text { EOU1 } \\
\text { EOU2 }\end{array}$ & $\begin{array}{l}0.973 \\
0.975\end{array}$ & $\begin{array}{c}3.46 \\
8\end{array}$ & 1.113 & 0.946 & 0.974 & 0.949 \\
\hline $\begin{array}{c}\text { Accuracy } \\
\text { (AC) }\end{array}$ & $\begin{array}{l}\mathrm{AC} 1 \\
\mathrm{AC} 2 \\
\end{array}$ & $\begin{array}{l}0.935 \\
0.941\end{array}$ & $\begin{array}{c}3.63 \\
7 \\
\end{array}$ & 1.134 & 0.863 & 0.936 & 0.880 \\
\hline $\begin{array}{l}\text { Content } \\
\text { (CO) }\end{array}$ & $\begin{array}{l}\mathrm{CO} 1 \\
\mathrm{CO} 2 \\
\mathrm{CO} 3 \\
\end{array}$ & $\begin{array}{l}0.930 \\
0.908 \\
0.929 \\
\end{array}$ & $\begin{array}{c}3.42 \\
5\end{array}$ & 1.016 & 0.912 & 0.945 & 0.850 \\
\hline $\begin{array}{c}\text { Format } \\
(\mathrm{FO})\end{array}$ & $\begin{array}{l}\text { FO1 } \\
\text { FO2 } \\
\end{array}$ & $\begin{array}{l}0.949 \\
0.932 \\
\end{array}$ & $\begin{array}{c}3.48 \\
9\end{array}$ & 1.044 & 0.870 & 0.939 & 0.885 \\
\hline $\begin{array}{l}\text { Timeliness } \\
(\mathrm{TI})\end{array}$ & $\begin{array}{l}\text { TI1 } \\
\text { TI2 }\end{array}$ & $\begin{array}{l}0.969 \\
0.973 \\
\end{array}$ & $\begin{array}{c}3.41 \\
7\end{array}$ & 1.084 & 0.940 & 0.971 & 0.943 \\
\hline $\begin{array}{c}\text { Perceived } \\
\text { Usefulness } \\
\text { (PU) }\end{array}$ & $\begin{array}{l}\text { PU1 } \\
\text { PU2 } \\
\text { PU3 }\end{array}$ & $\begin{array}{l}0.954 \\
0.932 \\
0.911 \\
\end{array}$ & $\begin{array}{c}3.25 \\
9\end{array}$ & 1.125 & 0.925 & 0.952 & 0.869 \\
\hline $\begin{array}{l}\text { Intention to } \\
\text { Continue } \\
\text { Using Car } \\
\text { Navigation } \\
\text { Systems } \\
\text { (INT) }\end{array}$ & $\begin{array}{l}\text { INT1 } \\
\text { INT2 } \\
\text { INT3 }\end{array}$ & $\begin{array}{l}0.951 \\
0.947 \\
0.932\end{array}$ & $\begin{array}{c}3.50 \\
7\end{array}$ & 1.077 & 0.938 & 0.960 & 0.890 \\
\hline
\end{tabular}

Note: $\mathrm{M}=$ Mean; $\mathrm{SD}=$ Standard Deviation, $\alpha=$ Cronbach's alpha; $\mathrm{CR}=$ Composite Reliability, AVE = Average Variance Extracted.

Key: EOU: ease-of-use, AC: accuracy, CO: content, FO: format, TI: timeliness, PU: perceived usefulness, INT: intention to continue using car navigation systems.

The degree to which the articles distinguish among concepts or measure different constructs is demonstrated by discriminant validity. Cross-loadings as well as Fornell-Larcker were employed to analyse the measurement model's discriminant validity. Generally, cross-loadings are employed as the initial step in examining discriminant validity of the markers. In this research, the outer loadings of the study markers surpassed the cross-loadings with different parameters, which supported the cross-loading conditions. (refer to Table 2). 
Integrating Technology Acceptance Model and End-User Computing Satisfaction to Explain the Intention to Continue Using Car Navigation Systems in UAE

Table 2: Results of discriminant validity by the cross loading

\begin{tabular}{|c|c|c|c|c|c|c|c|}
\hline & $\mathrm{EOU}$ & $\mathrm{AC}$ & $\mathrm{CO}$ & $\mathrm{FO}$ & $\mathrm{TI}$ & INT & SAT \\
\hline EOU1 & 0.973 & 0.611 & 0.720 & 0.603 & 0.556 & 0.576 & $\begin{array}{c}0.40 \\
9 \\
0.42\end{array}$ \\
\hline EOU2 & 0.975 & 0.610 & 0.723 & 0.637 & 0.579 & 0.586 & $\begin{array}{c}6 \\
0.39\end{array}$ \\
\hline $\mathrm{AC} 1$ & 0.589 & 0.935 & 0.622 & 0.586 & 0.585 & 0.516 & $\begin{array}{c}9 \\
0.41\end{array}$ \\
\hline $\mathrm{AC} 2$ & 0.587 & 0.941 & 0.625 & 0.619 & 0.587 & 0.539 & $\begin{array}{c}2 \\
0.36\end{array}$ \\
\hline $\mathrm{CO} 1$ & 0.700 & 0.614 & 0.930 & 0.604 & 0.590 & 0.614 & $\begin{array}{c}6 \\
0.38\end{array}$ \\
\hline $\mathrm{CO} 2$ & 0.667 & 0.616 & 0.908 & 0.669 & 0.608 & 0.562 & $\begin{array}{c}9 \\
0.34\end{array}$ \\
\hline $\mathrm{CO} 3$ & 0.682 & 0.610 & 0.929 & 0.639 & 0.592 & 0.580 & $\begin{array}{c}7 \\
0.47\end{array}$ \\
\hline FO1 & 0.635 & 0.628 & 0.676 & 0.949 & 0.535 & 0.575 & $\begin{array}{c}0 \\
0.47\end{array}$ \\
\hline $\mathrm{FO} 2$ & 0.558 & 0.579 & 0.619 & 0.932 & 0.575 & 0.497 & $\begin{array}{c}3 \\
0.45\end{array}$ \\
\hline TI1 & 0.562 & 0.603 & 0.613 & 0.577 & 0.969 & 0.507 & $\begin{array}{c}0 \\
0.41\end{array}$ \\
\hline TI2 & 0.570 & 0.610 & 0.642 & 0.566 & 0.973 & 0.541 & $\begin{array}{c}2 \\
0.31\end{array}$ \\
\hline PU1 & 0.550 & 0.501 & 0.567 & 0.532 & 0.492 & 0.954 & $\begin{array}{c}7 \\
0.31\end{array}$ \\
\hline PU2 & 0.508 & 0.491 & 0.567 & 0.506 & 0.464 & 0.932 & $\begin{array}{c}7 \\
0.38\end{array}$ \\
\hline PU3 & 0.602 & 0.572 & 0.635 & 0.558 & 0.546 & 0.911 & $\begin{array}{c}2 \\
0.95\end{array}$ \\
\hline INT1 & 0.413 & 0.406 & 0.374 & 0.461 & 0.431 & 0.330 & $\begin{array}{c}1 \\
0.94\end{array}$ \\
\hline INT2 & 0.412 & 0.419 & 0.391 & 0.485 & 0.441 & 0.379 & $\begin{array}{c}7 \\
0.93\end{array}$ \\
\hline INT3 & 0.387 & 0.398 & 0.360 & 0.471 & 0.380 & 0.323 & 2 \\
\hline
\end{tabular}

Key: EOU: ease-of-use, AC: accuracy, CO: content, FO: format, TI: timeliness, PU: perceived usefulness, INT: intention to continue using car navigation systems.

Table 3 shows the outcomes for discriminant validity by employing the Fornell-Larcker condition. It was discovered that the AVEs' square root on the diagonals (displayed in bold) is bigger than the correlations among constructs (corresponding row as well as column values), suggesting a markers in comparison to the other concepts in the model. This is termed as good discriminant validity. Furthermore, the exogenous constructs have a correlation of less than 0.85 (Awang, 2014). Therefore, all constructs had their discriminant validity fulfilled satisfactorily strong association between the concepts and their respective

Table 3: Results of discriminant validity by Fornell-Larcker criterion

\begin{tabular}{|c|c|c|c|c|c|c|c|c|}
\hline & \multirow[t]{2}{*}{ Factors } & 1 & 2 & 3 & 4 & 5 & 6 & 7 \\
\hline & & $\mathrm{AC}$ & $\mathrm{CO}$ & $\mathrm{EOU}$ & $\mathrm{FO}$ & INT & PU & TI \\
\hline 1 & $\mathrm{AC}$ & 0.938 & & & & & & \\
\hline 2 & $\mathrm{CO}$ & 0.665 & 0.922 & & & & & \\
\hline \multirow[t]{4}{*}{3} & $\mathrm{EOU}$ & 0.627 & 0.741 & 0.974 & & & & \\
\hline & FO & 0.643 & 0.690 & 0.637 & 0.941 & & & \\
\hline & INT & 0.432 & 0.398 & 0.428 & 0.501 & 0.943 & & \\
\hline & PU & 0.563 & 0.635 & 0.597 & 0.572 & 0.365 & 0.932 & \\
\hline 4 & TI & 0.625 & 0.647 & 0.583 & 0.588 & 0.443 & 0.540 & $\begin{array}{c}0.97 \\
1\end{array}$ \\
\hline
\end{tabular}

Note: Diagonals represent the square root of the average variance extracted while the other entries represent the correlations.

Key: EOU: ease-of-use, AC: accuracy, CO: content, FO: format, TI: timeliness, PU: perceived usefulness, INT: intention to continue using car navigation systems. 


\section{Measurement Model Assessment}

The structural model can be tested by computing beta $(\beta)$, $\mathrm{R}^{2}$, and the corresponding t-values by implementing the bootstrapping procedure using 5000 resamples.

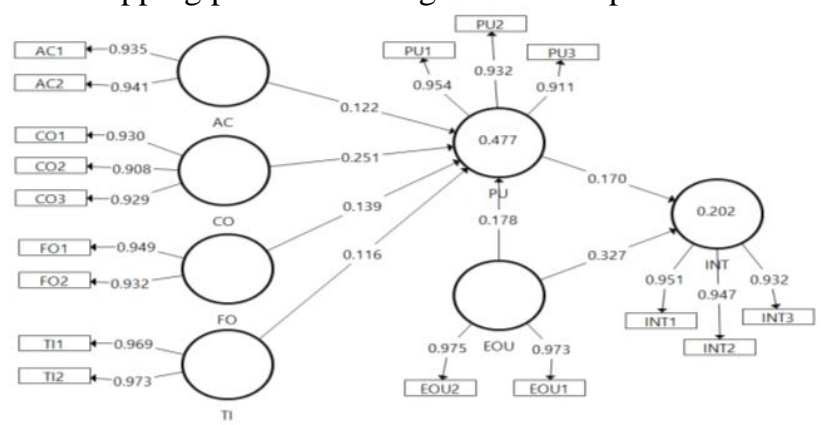

Key: EOU: ease-of-use, AC: accuracy, CO: content, FO: format, TI: timeliness, PU: perceived usefulness, INT: intention to continue using car navigation systems.

Fig. 2: PLS algorithm results

\section{a. Hypotheses Tests}

Figure 2 and Table 4 discusses about the assessment of the structural model, showing the results of the hypothesis tests, with 7 out of the 7 hypotheses are supported. Ease-of-use, accuracy, content, format, and timeliness has a positive influence on perceived usefulness. Hence, $\mathrm{H} 1, \mathrm{H} 2, \mathrm{H} 3, \mathrm{H} 4$ and $\mathrm{H} 5$ are accepted with $(\beta=0.178, \mathrm{t}=2.346, \mathrm{p}<0.05)$, $(\beta=0.122, \mathrm{t}=1.836, \mathrm{p}<0.05), \quad(\beta=0.251, \mathrm{t}=3.396, \mathrm{p}$ $<0.001), \quad(\beta=0.139, \mathrm{t}=1.999, \mathrm{p} \quad<0.05) \quad$ and $(\beta=0.116, \mathrm{t}=1.811, \mathrm{p}<0.05)$ respectively. Ease-of-Use and perceived usefulness have a positive influence on intention to continue using car navigation systems. Hence, $\mathrm{H} 6$ and $\mathrm{H} 7$ are accepted with $(\beta=0.327, \mathrm{t}=4.788$, $\mathrm{p}$ $<0.001)$ and $(\beta=0.170, \mathrm{t}=2.546, \mathrm{p}<0.01)$ respectively. The strength of the relationship between exogenous and endogenous constructs are measured by the standardised path coefficients, which in this case show that the direct effects of content on perceived usefulness is stronger than the influence of other variables. The values of $\mathrm{R}^{2}$ have an acceptable level of explanatory power, indicating a substantial model.

Table 4: Structural path analysis result

\begin{tabular}{|c|c|c|c|c|c|c|c|}
\hline Hypothesis & $\begin{array}{c}\text { Relationshi } \\
\mathrm{p}\end{array}$ & $\begin{array}{c}\text { Std } \\
\text { Beta }\end{array}$ & $\begin{array}{c}\text { Std } \\
\text { Error }\end{array}$ & t-value & $\mathrm{p}$-value & Decision & $\mathrm{R}^{2}$ \\
\hline $\mathrm{H} 1$ & $\mathrm{EOU} \rightarrow \mathrm{PU}$ & 0.178 & 0.076 & 2.346 & 0.010 & Supported & $\begin{array}{c}0.4 \\
8\end{array}$ \\
\hline $\mathrm{H} 2$ & $\mathrm{AC} \rightarrow \mathrm{PU}$ & 0.122 & 0.067 & 1.836 & 0.033 & Supported & \\
\hline H3 & $\mathrm{CO} \rightarrow \mathrm{PU}$ & 0.251 & 0.074 & 3.396 & 0.000 & Supported & \\
\hline $\mathrm{H} 4$ & $\mathrm{FO} \rightarrow \mathrm{PU}$ & 0.139 & 0.070 & 1.999 & 0.023 & Supported & \\
\hline H5 & $\mathrm{TI} \rightarrow \mathrm{PU}$ & 0.116 & 0.064 & 1.811 & 0.035 & Supported & \\
\hline H6 & $\mathrm{EOU} \rightarrow \mathrm{INT}$ & 0.327 & 0.068 & 4.788 & 0.000 & Supported & $\begin{array}{c}0.2 \\
0\end{array}$ \\
\hline $\mathrm{H} 7$ & $\mathrm{PU} \rightarrow \mathrm{INT}$ & 0.170 & 0.067 & 2.546 & 0.006 & Supported & \\
\hline
\end{tabular}

Key: EOU: ease-of-use, AC: accuracy, CO: content, FO: format, TI: timeliness, PU: perceived usefulness, INT: intention to continue using car navigation systems.

\section{b. Importance-Performance Map Analysis (IPMA)}

IPMA was employed as a post-hoc PLS procedure in this study, with the intention to continue using car navigation systems used as the outcome construct. The IPMA provides an estimation of the total effects corresponding to the importance of predecessor constructs in affecting the target construct (intention to continue using car navigation systems); the average latent variable scores correspond to their performance, whereas the index values' (performance scores) calculation was achieved by rescaling the scores of the latent constructs to within a range from 0 (lowest performance) to 100 (highest performance). IPMA enhances the results of PLS analysis by focusing more on the average value for latest constructs along with their indicators while the path coefficients analysis is being conducted. The results for total effects (importance) and index values (performance) of the IPMA of the outcome construct intention to continue using car navigation systems is displayed in Tables 5 .

Table 5: IPMA for intention to continue using car navigation systems

\begin{tabular}{lcc}
\hline \multicolumn{1}{c}{ Latent constructs } & $\begin{array}{c}\text { Total effect of the construct } \\
\text { intention to continue using car } \\
\text { navigation systems (Importance) }\end{array}$ & $\begin{array}{c}\text { Index values } \\
\text { (Performance) }\end{array}$ \\
\hline Ease-of-Use (EOU) & 0.346 & 61.71 \\
Accuracy (AC) & 0.020 & 65.96 \\
Content (CO) & 0.045 & 60.62 \\
Format (FO) & 0.024 & 62.29 \\
Timeliness (TI) & 0.020 & 60.45 \\
Perceived Usefulness (PU) & 0.163 & 56.59 \\
\hline
\end{tabular}

The total effects score and index values were plotted on a priority map (Figure 3 ). It can be concluded from these scores that 'ease-of use' is a primary factor in deciding whether one wants to continue using the car navigation systems owing to its impotance in comparison with the proposed model's remaining constructs. 


\section{Integrating Technology Acceptance Model and End-User Computing Satisfaction to Explain the Intention to Continue Using Car Navigation Systems in UAE}

While there exists an apparent gap on the importance of factors for determining intention to continue using car navigation systems, these factors have similar performance. IPMA aims to identify the predecessors that have both relatively high importance (with strong total effect) and relatively low performance for the target construct (with low average latent variable scores). Particular attention may be given to the attributes of these constructs, which can be potential areas for improvement. In sum, in order to improve the intention to continue using car navigation systems, the managerial activities should focus on enhancing the performance of ease-of-use and perceived usefulness.

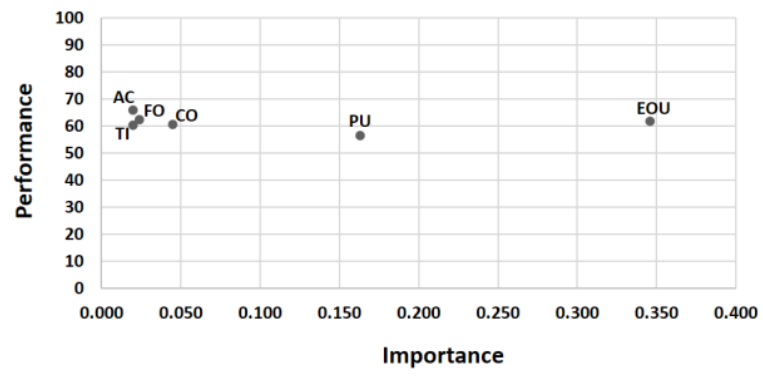

Key: EOU: ease-of-use, AC: accuracy, CO: content, FO: format, TI: timeliness, PU: perceived usefulness

Fig. 3: IPMA (Priority Map) for intention to continue using car navigation systems.

\section{Discussion}

The study found that ease of use positively affects perceived usefulness of car navigation systems among drivers with private licenses in the United Arab Emirates, this is supported by previous studies [19]. It is explained by the fact that the more the car navigation systems are easy to use, including learning its operation easily, the more using car navigation systems save time, improves driving effectiveness and hence become generally useful.

Further, it was found that each of accuracy, content, format, and timeliness positively affect perceived usefulness, this is supported by previous studies. It is explained by the fact that the more accurate the car navigation system and driver is actually satisfied with its performance, provide a precise and sufficient information that meet driver's needs, present the output in a useful format with suitable clarity, present the needed information instantly with up-to-date output. The more using car navigation systems save time, improves driving effectiveness and hence become generally useful.

Moreover, the study also found that ease of use positively influenced intention to continue using car navigation systems, this is supported by previous studies. It is explained by the fact that the more the car navigation systems are easy to use, including learning its operation easily, the more drivers have the motivation to use car navigation systems continuously in the future, promote others use car

\section{APPENDIX}

\section{Appendix A}

Instrument for varibles navigation systems, and decide to actually use it in the future.

Lastly, the study also found that perceived usefulness significantly influence intention to continue using car navigation systems, which is in line with previous studies. It can be explained by the notion that the more using car navigation systems save time, improves driving effectiveness and hence become generally useful, the more drivers have the motivation to use car navigation systems continuously in the future, promote others use car navigation systems, and decide to actually use it in the future.

\section{IMPLICATIONS, LIMITATIONS AND FUTURE DIRECTIONS}

The navigation system usage has the possibility to increase traffic safety: it facilitates the strategic task by eliminating the navigation task. The driver can direct more dedicated attention on the tactical and operational tasks while driving. Otherwise, drivers may adjust their behaviour in an unsafe way when using the navigation system. Such opposing behavioural alteration could decrease the safety effect [19]. In the context of UAE, the result can benefit the authorities and car manufacturers to focus on enhancing navigation systems to make it more integrated, useful, and easy to use.

There main limitation in this study is related to geography as it was conducted in the city of Abu Dhabi only. For generalization, the researcher recommends to investigate this study in other geographic areas in the country. In the future research, it is suggested to examine drivers' genders and while it has a great impact on the drivers' risky behaviors during the drivers.

\section{CONCLUSION}

The purpose of this article was to examine factors that influence intention to continue using car navigation systems based on the technology acceptance model an end-user computing satisfaction model which are (accuracy, content, format, timeliness, ease of use, usefulness, and intention to continue using). It has provided evidence from leading scholars in the field on the notion of car navigation system utilization in the UAE. Regardless of various constraints to the study, the results have been encouraging, as it has managed to throw some lights on how to encourage the use of navigation systems in UAE. The results revealed that the seven hypotheses are significant where ease of use, accuracy, content, format, and timeliness predicted perceived usefulness which in turn influenced the intention to use. The independent variables significantly explain $48 \%$ of perceived usefulness and $20 \%$ of intention to continue using car navigation system. The implications of this study have been deliberated, some directions for future research have been suggested. 


\begin{tabular}{|c|c|}
\hline Varible & Measure \\
\hline $\begin{array}{l}\text { Ease-of-Use } \\
\quad(\text { EOU })\end{array}$ & $\begin{array}{l}\text { EOU1: Car navigation systems are easy to use. } \\
\text { EOU1: Learning to operate car navigation systems is easy. }\end{array}$ \\
\hline $\begin{array}{l}\text { Accuracy } \\
\quad(\mathrm{AC})\end{array}$ & $\begin{array}{l}\text { AC1: Car navigation systems are accurate. } \\
\text { AC2: I am satisfied with the accuracy of the car navigation } \\
\text { systems. }\end{array}$ \\
\hline $\begin{array}{l}\text { Content } \\
\text { (CO) }\end{array}$ & $\begin{array}{l}\text { CO1: The car navigation systems provide the precise information } \\
\text { I need. } \\
\text { CO2: The information content in car navigation systems meet } \\
\text { my needs. } \\
\text { CO3. The car navigation systems provide sufficient information }\end{array}$ \\
\hline $\begin{array}{l}\text { Format } \\
\text { (FO) }\end{array}$ & $\begin{array}{l}\text { FO1: I think the output from car navigation systems is presented } \\
\text { in a useful format. } \\
\text { sO2: The information clearly presented in car navigation } \\
\text { systems. }\end{array}$ \\
\hline $\begin{array}{l}\text { Timeliness } \\
\text { (TI) }\end{array}$ & $\begin{array}{l}\text { TI1: I get the information I need in time from car navigation } \\
\text { systems } \\
\text { TI2: The car navigation systems provide up-to-date information }\end{array}$ \\
\hline $\begin{array}{l}\text { Perceived } \\
\text { Usefulness } \\
\quad(P U)\end{array}$ & $\begin{array}{l}\text { PU1: Using car navigation systems would save me much time. } \\
\text { PU2: Car navigation systems would enhance my effectiveness in } \\
\text { driving. } \\
\text { PU3: Overall, car navigation systems would be useful. }\end{array}$ \\
\hline $\begin{array}{l}\text { Intention to } \\
\text { Continue Using }\end{array}$ & $\begin{array}{l}\text { INT1: I intend to use car navigation systems continuously in the } \\
\text { future. }\end{array}$ \\
\hline $\begin{array}{l}\text { Car Navigation } \\
\text { Systems } \\
\text { (INT) }\end{array}$ & $\begin{array}{l}\text { INT2: I will recommend others to use car navigation systems. } \\
\text { INT3: I will frequently use car navigation systems in the future. }\end{array}$ \\
\hline
\end{tabular}

\section{REFERENCES}

[1] S. Alkhateri, A. E. Abuelhassan, G. S. A. Khalifa, M. Nusari \& A. Ameen, (2018). The Impact of perceived supervisor support on employees turnover intention : The Mediating role of job satisfaction and affective organizational commitment. International Business Management, 12(7), pp. 477-492. http://doi.org/10.3923/ibm.2018.477.492.

[2] A. Ameen \& K. Ahmad, (2011). The Role of Finance Information Systems in anti financial corruptions: A theoretical review. In 11 International Conference on Research and Innovation in Information Systems (ICRIIS'11 (pp. 267-272). Ieee. http://doi.org/10.1109/ICRIIS.2011.6125725

[3] A. Ameen \& K. Ahmad, (2013). A Conceptual Framework of Financial Information Systems to reduce corruption. Journal of Theoretical and Applied Information Technology, 54(1), pp. 59-72.

[4] A. Ameen \& K. Ahmad, (2014). A Systematic Strategy for Harnessing Financial Information Systems in Fighting Corruption Electronically. In Knowledge Management International Conference (KMICe) 2014, 12 15 August 2014, Malaysia pp. 12-15. Retrieved from http://www.kmice.cms.net.my/

[5] A. Ameen \& K. Ahmad, (2012). Towards Harnessing Financial Information Systems in Reducing Corruption : A Review of Strategies. Australian Journal of Basic and Applied Sciences, 6(8), pp. 500-509.

[6] Venkatesh And Davis, F. (2000). A Theoretical Extension of the Technology Acceptance Model : Four Longitudinal Field Studies, pp. 186-204.

[7] F. D. Davis, (1989). perceived Usefulness, Perceived ease of use, and User Acceptence of inforamtion technology, 13(3), pp. 319-340.

[8] C. Chang, (2013). Exploring the determinants of e-learning systems continuance intention in academic libraries. Library Management, 34(1/2), pp. 40-55. http://doi.org/10.1108/01435121311298261

[9] S. Sahadev \& K. Purani, (2008). Modelling the consequences of e-service quality. Marketing Intelligence \& Planning, 26(6), pp. 605-620. http://doi.org/10.1108/02634500810902857Ha.

[10] M. Khalifa, \& K. N. Shen, (2008). Explaining the adoption of transactional B2C mobile commerce. Journal of Enterprise Information Management, 21(2), pp. 110-124. http://doi.org/10.1108/17410390810851372

[11] M. Kocaleva \& S. Zdravev, (2014). Research on UTAUT Application in Higher Education Institution. International Conference on Information Technology and Development of Education.

[12] Y.-S. Wang, H.-H. Lin \& P. Luarn, (2006). Predicting consumer intention to use mobile service. Information Systems Journal, 16(2), pp. 157-179. http://doi.org/10.1111/j.1365-2575.2006.00213.x

[13] O. Isaac, Z. Abdullah, T. Ramayah, \& M. Mutahar Ahmed, (2017) Examining the Relationship Between Overall Quality, User Satisfaction and Internet Usage: An Integrated Individual, Technological, Organizational and Social Perspective. Asian Journal of Information Technology, 16(1), pp. 100-124. http://doi.org/10.3923/ajit.2017.100.124

[14] O. Isaac, Z. Abdullah, T. Ramayah, A. M. Mutahar \& I. Alrajawy, (2017). Towards a Better Understanding of Internet Technology Usage by Yemeni Employees in the Public Sector: An Extension of the Task-Technology Fit (TTF) Model. Research Journal of Applied Sciences, 12(2), pp. 205-223. http://doi.org/10.3923/rjasci.2017.205.223 